\title{
Formal and Informal Irrigation in the Andean Countries. An Overview
}

\author{
Álvaro Martín Gutiérrez-Malaxechebarría* \\ Recibido: 20I4-0I-24 Aprobado: 20I4-05-06 Disponible en línea: 2014-07-27 \\ doi:I0.III44/javeriana.CRDII-74.fiac \\ Cómo citar este artículo: Gutiérrez-Malaxechebarría, A. (2014). Formal and Informal Irrigation in the Andean \\ Countries. An Overview. Cuadernos de Desarrollo Rural, ${ }_{1 I}(74)$, 75-99. http://dx.doi.org/10.III44/Javeriana.CRDII-74. \\ fiac
}

\begin{abstract}
This work is an empiric-theory revision which evidences the existence of two irrigation sectors in the Andean countries: a formal one, mainly located in plain low lands, controlled by the government, mostly directed to agribusiness producers; the other sector, informal irrigation, is directly managed by the producers, usually family farmers, without government control and without being reported in national statistics; this second sector is principally located in the Andean mountains. Nowadays there are several institutions for the access to water which are associated to different stakeholders, so conflicts between different kinds of users emerge.
\end{abstract}

\section{Keywords:}

agricultural development; irrigation; Andes; informal irrigation; farming systems; water management

* Estudiante de doctorado en Estudios Ambientales y Rurales de la Pontificia Universidad Javeriana. Profesor de la Facultad del Medio Ambiente y los Recursos Naturales Universidad Distrital Francisco José de Caldas. Email: malaxechebarria@yahoo.com

\section{cc $\$ \otimes$}




\section{Riego formal e informal en los países andinos. Una visión general}

\section{Resumen}

Este trabajo es una revisión empírico-teórica que pone de manifiesto la existencia de dos sectores de riego en los países andinos: uno formal, ubicado principalmente en las tierras bajas o llanuras, controladas por el Gobierno y dirigidas a los productores agroindustriales en su mayoría. El otro sector que cuenta con riego informal es administrado directamente por los productores y por lo general son familias agricultoras, sin control gubernamental y que no han sido reportados en las estadísticas nacionales. Este segundo sector se encuentra principalmente en las montañas andinas. Hoy en día hay varias instituciones para el acceso al agua que están asociadas con las diferentes partes involucradas, por lo que han surgido conflictos entre los diferentes tipos de usuarios.

\section{Palabras clave:}

desarrollo agrícola; riego; Andes; riego informal; sistemas de cultivo; gestión del agua

\section{Irrigation formelle et informelle dans les pays andins. Une vision générale}

\section{Résumé}

Ce travail est une révision empirique-théorique qui met en évidence l'existence de deux (2) secteurs d'irrigation dans les pays andins : un secteur formel, situé principalement dans les plaines, contrôlées par le gouvernement et visées, par sa plus grande partie, aux producteurs agro-industriels. L'autre secteur qui a une irrigation informelle est géré directement par les producteurs et, en général, par ceux qui sont des agriculteurs familiaux, sans contrôle gouvernemental et sans des rapports dans les statistiques nationales. Ce deuxième secteur se trouve principalement aux montagnes andines. En ce moment, il y a des différentes institutions pour l'accès à l'eau qui sont associées aux différentes parties impliquées et ceci fait surgir des conflits parmi les différents types d'usagers.

\section{Mots-clés:}

développement agricole; irrigation ; Andes; irrigation informelle; systèmes de culture; gestion de l'eau 


\section{Introduction}

Although they have social and ecosystem differences, Bolivia, Colombia, Ecuador, Perú and Venezuela are called Andean countries due to the fact that they share the presence of the northern and central Andes as well as some common patterns, like those related to irrigation schemes, as it will be described.

The variability of climates and the ancient establishment of population in zones where the access to water was limited encouraged the early installation of irrigated agriculture. Zimmerer (1995) demonstrated that irrigation was already used in Taratá (Cochabamba, Bolivia) 3500 years ago, which allowed the settlement of later empires such as Tiwanaku, Inca and Spanish.

Although the ancient developments in irrigation given in the Andean zone are the most widely known, such developments also took place in a wide variety of zones which comprehend floodable coastal plains, desert zones and the Amazon basin. They were adapted to different environmental conditions and characterized by their innovation capacity, high efficiency (Branch et ál., 2007) and adaptation to local conditions.

Pre-Hispanic processes of technological development were abruptly interrupted during the European conquest due to three big factors: I) the abandonment of big areas caused by the population collapse (Trawick, 200I, p. 2I; 2003, p. 982); 2) the implementation of new production systems; and 3) other factors, still unknown, probably associated to droughts (Branch et al., 2007).

Although some irrigated areas were preserved and Hispanic crops which required irrigation were established, it was not until the end of the $19^{\text {th }}$ century and the beginning of the $20^{\text {th }}$ century that important developments of irrigated agriculture appeared again'.

Modern irrigation projects started to be developed by governmental initiative. In some cases, like the ones in Peru and Ecuador, the projects were motivated by the importance of export crops such as sugar cane, cotton (Alfaro, Guardia, Golte, Masson \& Oré, 1993, p. 134) and banana. In Colombia and Venezuela, the construction of public irrigation systems originated in order to meet the internal demand for food.

The major boost of these irrigation systems in the region took place between the 30's and the 60's, partly because of processes of agrarian reform and government efforts to intensify agriculture. Modernization of irrigation systems, as part of Green Revolution packages, was driven as a state's imposition and response to

\footnotetext{
I The extension of pre-Hispanic irrigated area in Perú was 840000 hectares; it was not until the $20^{\text {th }}$ century that this area was recuperated (Palerm-Viqueira, 2010, p. 785). Despite this in the Moche Valley, only 35 to 40 per cent of the anciently irrigated area is irrigated nowadays (Ortloff, Feldman \& Moseley, 1985).
} 
people soliciting them scope to modernize their agricultural systems (Boelens \& Hoogendam, 2002) and improve their production. In the cases in which farmers did not have access to the state-promoted agricultural modernization programs, the green revolution developments, including irrigation systems, were autonomously adapted by great masses of farmers; this situation generated an ambiguous phenomenon of adaptation to their surroundings and ignorance in relation to technology.

In summary, and according to Trawick (200I, p. 19), the irrigation systems in the Andean countries have been through three historical processes: I) the establishment, in pre-Hispanic times, of methods which attempted to manage a scarce resource, 2) a massive reduction of water and land use during the colonial process, and 3) a gradual re-intensification which responded to population growth, combined with the increase of economies aimed at exportation and export substitution in the green revolution framework.

As a result of these processes, it is possible to define two types of irrigation systems: formal and informal ${ }^{2}$. The formal systems are those, public or private, that have been developed with universally accepted technical standards under the state institution and, for their characteristics, have been reported in national statistics. On the other hand, the informal irrigation systems are those developed by farmers themselves, without meeting the state's formal requirements, which are not reported in national statistics (Gutiérrez-Malaxechebarría, 2013).

Although it is common to observe the coexistence, in one zone, of diverse types of agricultural production and irrigation systems in the Andean countries, a differentiated geographical distribution which predominates in the irrigation systems is evidenced: medium and large scale ${ }^{3}$ formal irrigation systems developed in low plain zones, and small scale systems, mainly informal ones, developed by family farmers in mountainous zones; this constitutes a dual system, or two tiered system as Trawick (2003, p. 980) named it when referring to the vertical nature of the Andes.

Now, this is a revision article, based on an empirical-theorical approach. It was made based on literature review, interviews, case studies and field observations, and aims to describe and evidence general characteristics of irrigation systems in the Andean countries. At the beginning, irrigation institutions are discussed, followed

\footnotetext{
2 There are also various examples of what we can define as mixed systems, but this binary distinction is heuristically useful and helps to organize the following exposition.

3 In Colombia, a medium scale irrigation district is that which irrigates between 500 and 5000 hectares, and a large scale irrigation system is that which irrigates more than 5000 hectares. Similar classifications are used in the other Andean countries.
} 
by descriptions that go from formal to informal irrigation systems; at the end, conclusions are presented, evidencing that irrigation systems are diverse, complex and work in a panorama were different institutions, visions, agricultural systems, and economic pressures over water coexist.

\section{Irrigation management in the Andean countries}

Irrigation systems are composed of human agents along with physical infrastructure, social infrastructure, institutional infrastructure and biophysical processes that interact in complex ways (Cifdaloz, Regmi, Anderies \& Rodríguez, 20I0, p. 2), so irrigation water management is regulated by great variety of institutions. Now, understanding institutions as the rules that guide stakeholders to politic and economic decision-making (North \& Thomas, 1978; North, 1993), an irrigation institution is the set of working rules for supplying and using irrigation water in a particular location (Ostrom, 1992, p. 19).

Zimmerer (2000, p. 15I) affirms that in the Andes the organization of irrigation has been shaped by processes that combine social conflict and co-operation, struggle and political consolidation, and human change of the environment. In Andean basins, water rights and rules to access to it can be developed under the coexistence of diverse logics in complex and fast changing processes. In this way, even in one same system or community, various types of water rights can come up simultaneously (Cremers, Ooijevaar \& Boelens, 2005; Roth, Rutgerd \& Zwarteveen, 2005; Von Benda-Beckmann, Von Benda-Beckmann \& Spiertz, 1998).

In some Andean communities, the institutions which regulate irrigation resulted from an adaptation of those of pre-Hispanic origin (Boelens \& Gelles, 2005). In other cases, such institutions are more recent and obey to changes in the agricultural production systems. Among the norms multiplicity, we can mention state and communal rules, and even norms which are about to be established; the coexistence of these rules can generate conflicts and gaps in the definition of who has right to water, how much water they can access and under what conditions.

However, many of those institutions, sometimes local, small scale and informal, meet all, or most, of the principles of long-enduring self-organized irrigation systems mentioned by Ostrom (1992), which are: clearly defined boundaries, proportional equivalence between benefits and costs, collective-choice arrangements, monitoring design, graduated sanctions, conflict resolution mechanisms, minimal recognition of rights to organize and nested enterprises. 
It was expected that the Andean countries' new constitutions, established in the last decade of the 2oth century and the first decade of the $2 \mathrm{I}^{\mathrm{st}}$ century, would allow the institutional incorporation of these complexities. Although the ethnic (indigenous and African descendant) communities' rights to land management were recognized, the non-ethnic social groups like peasants were not given such rights. Despite the advances done, there is still a lack of laws and regulations which guarantee the incorporation and recognition of plural institutions (Boelens, 2009; Palacios, 2003)4.

Public irrigation policies have been influenced by three great paradigms which appeared in the last 30 years: the first one was based on the state preeminent action, time when most of the irrigation districts were built; then, it was on the collective action and, more recently, on the individual action and the market regulation (Kuper, 20II). Neoliberal policies ${ }^{5}$ have motivated the process of transference of irrigation systems from the state to the users, based on the state's need to reduce costs by transferring those costs to the farmers, and paradoxically on the well-known thesis that self-governing systems increase operation efficiency ${ }^{6}$.

As a result of these processes, users associations (asociaciones de usuarios) have appeared in Bolivia and Colombia, irrigation committees (comités de riego) or boards of irrigators (juntas de regantes) in Venezuela and boards of users (juntas de usuarios) in Ecuador; they have allowed irrigators commissions (traditional), irrigation committees (modern) and boards of users (basin users associations) to coexist in Perú, generating conflicts among them occasionally.

These policies and processes have been controversial for their ambiguous results since, although there are several cases which show that the local users' participation in water management makes the irrigation systems more efficient, even and sustainable (Alfaro et al., 1993; Boelens \& Doornbos, 200I; Boelens \& Gelles, 2005; Boelens \& Hoogendam, 2002; Canelón Pérez, 2008; Coward, 1977; Cremers et al., 2005; Lam, 200I; Maldonado Rojas, 2000; Mazabel, 2007; Ostrom, 2000; Trawick, 200I; 2003; Urrutia Cobo, 2006), it has been demonstrated that local administrations is not always the panacea (Boelens \& Dávila, 1998; Brooks, 2003; Gutiérrez, 2006; Urrutia Cobo,

4 Both references show how, despite the fact that national laws recognize and protect local rights, state policies and local rules and rights are usually in dispute.

5 During 1990's most Latin American countries' policies followed - or at least intended to follow- the Chilean Código de aguas (Water Code), which was established during the dictatorship. This way, water rights become a tradable commodity stimulating free markets in water use and management (De Vos, Boelens \& Bustamante, 2006, p. 39).

6 For example, Ostrom et al. (1994) showed that farmer-managed irrigation systems in Nepal tend to achieve average performance levels above those operated by the State. 
2006); these last authors have shown that irrigation systems transferences to users have not always had substantial effects on the operations development, maintenance, and agricultural and economic productivity of irrigated lands.

On the other hand, current policies of development establish that water, as a common-poll resource, must be managed by the state because only governments have the capacity to surmount them (Ostrom, Lam \& Lee, 1994, p. 197). So, it has been gradually generalized that irrigators must ask for water access permits (either paid for or for free). Although legalization of such access is not new for the formal irrigation sectors, it is expected that it will give the informal irrigators legal recognition over water use and allow the advance towards these systems' adequate formalization, which would need to involve technical support since the natural resources must be governed in a multilevel institutional scheme (Andersson \& Ostrom, 2007). However, an appropriate state water management requires proper support on technical information and deep knowledge of local conditions, but the Andean countries lack these tools. Besides, power struggles to control water by agribusinesses or even extractive enterprises are some of the main factors that define the social landscape and, therefore, conflicts with the irrigation systems in Andean countries.

\section{An overview to irrigation systems}

\section{I. Formal irrigation and agricultural development}

National statistics are characterized because they are not updated very often, and the data belonging to each country change according to the source which is studied (see, for example, CIA, 2009; FAO, 20I0; ICID, 2010; Thenkabail et al., 2009; GutiérrezMalaxechebarría, Prime \& Revillion, 2013). However, areas reported by those sources correspond to a consensus built on the data reported by governmental or multilateral entities, and refer only to formally irrigated areas.

The formal and large scale irrigation systems are located in warm lands on the coastal plains, except for those in Bolivia; also, they are located in the inter-Andean valleys in Colombia, the foothills in the Orinoco region in Venezuela, in eastern Bolivia and, marginally, in the fertile high plateaus in Ecuador and Colombia.

In these zones, mechanized and business agriculture has been benefited because of the closeness to transport infrastructure, the topography, easier access to capital and lower vulnerability to variations in hydrological regime, due to the fact that they are 
located in big basins' low areas; and also due to the natural characteristics of such low lands (climate, soil, humidity, temperature, luminosity), which represent comparative advantages in relation with other zones in the mentioned countries? ${ }^{7}$. Besides, it is common to see family and business agriculture mosaics as these two actors integrate mutually and functionally (Forero Álvarez et al., 20II), though with constant conflicts.

Formal irrigation can be oriented towards business agriculture, which is the case of private irrigation systems, and towards a combination of business and family agriculture, which is the case of state-originated irrigation systems ${ }^{8}$, also called irrigation districts.

According to their origin, formal irrigation systems can be managed by the state or by users associations, as in the case of irrigation districts; they can be directly managed by individuals or private associations, as in the case of private systems; or they can eventually be managed by mixed entities. In every case, however, the development of formal irrigation is designed and regulated by homogeneous norms based on engineering standards as well as on governmental and productive visions about water. Most of the formal irrigation systems in around the whole region, except for Perú, are private and irrigate big agribusiness systems. The irrigation districts, which feed smaller agribusiness and family agriculture systems, have lower participation. Now each country's irrigation systems will be exposed.

\section{a. Bolivia:}

Bolivian agricultural system is characterized as Trinitarian (Paz Ballivián, 1998) since there is a coexistence of typical productive relations of the peasants in the traditional area (high plateau, valleys and colonization zones in the tropic and subtropic), the business agriculturalists, and the indigenous communities in the eastern low lands. This sectorization resulted from the agrarian reform in 1953 , which eliminated latifundia in the high plateau by giving the land to indigenous groups and peasants, and simultaneously adjudicated big extensions of public lands in the east (Kay \& Urioste, 2007). Because of this, agricultural systems are characterized as capitalist in the east (Paz Ballivián, 2009), and as family farming in the Andean zone; this fact is confirmed with the data obtained in the study done by Forero

\footnotetext{
7 Nevertheless, informal irrigated agriculture has also been successful when introduced in the national markets, as it will be discussed later. On the other hand, dry agriculture has successfully adapted to the ecosystemic conditions; coffee and cacao crops are the best examples of successful dry agriculture.

8 There are irrigation systems built with NGO's aid, which usually benefit family farmers. These systems can be developed either as part of an irrigation system which already exists or as an entirely new system; they can be either formal or informal.
} 
Álvarez et al. (20II), whose findings were that only 36 per cent of the agricultural production in the plains region (east) corresponds to family farming systems, while 99 per cent of agriculture in the high plateau corresponds to the same kind.

In Bolivia there is irrigation conditioning in every altitudinal level (Morlon, 1996), but it is clearly differentiated, so are farming systems. The large scale formal irrigation systems and those oriented towards business agriculture, which are mostly private, are gathered in the eastern agribusiness zone, which is greatly linked to the external market. Formal irrigation, however, is marginal in the Andes; it is mainly state systems oriented towards family farming in the high plateau and the Cochabamba valleys, zones where most of the peasants, and indigenous people, who produce for the internal market are located (Paz Ballivián, 2009).

Governmental programs, as well as those proposed by non-governmental organizations, seeking to improve living conditions of the family farmers are centered in the Bolivian Andean zone. The change irrigation can produce in these zones is so big that Jáuregui, Olivares \& Colque (2005) found that after implementing small irrigation systems in five family farming zones (four in the Andean zone and one in El Chaco), an average increase of 236 per cent was reached in the family income. Despite such good economic results, Gutiérrez (2006) found that in Bolivia many of the formal irrigation projects may be abandoned or may lack maintenance due to the following facts: users are not involved when planning them; cultural, physiographic and climatological diversity are not taken into account; there are unequal power relationships between institutions and users associations, joined to the lack of proper criteria for the design and management. Similar results are evidenced for the Peruvian sierra by Solís (200I).

\section{b. Colombia}

In Colombia, as in the other Andean countries, the growth of irrigated areas has not been constant. In 1950 the irrigated area was 50000 hectares. Between 1960 and 1990 these areas grew notoriously until reaching 900000 hectares. In the 90's the violencepolitical instability duo and the economic aperture, which allowed the international competence to affect the returns of most crops negatively, had a direct negative impact on private investment in irrigation (Dinar \& Keck, 1997, p. 4); this, joined to the fact that the state did not continue to condition areas for irrigation, has caused the formally irrigated area in the country to relatively remain the same since then.

In this country 65 per cent of the formally irrigated area is private (FAO, 20I0); the remainder corresponds to public irrigation districts. In Colombia, as in the other 
Andean countries, the biggest efforts in formal irrigation, public as well as private, have taken place in the plain zones. According to interviews to officials at Incoder (the Colombian state institution responsible for irrigation), only 4.4 per cent of the total area which is formally irrigated (public and private) in Colombia corresponds to irrigation systems in mountainous zones.

Modern irrigation in Colombia started on the Caribbean coast thanks to private initiative aiming at establishing crops for exportation. Later, from the $30^{\prime}$ 's in the $20^{\text {th }}$ century, the state began the construction of large irrigation systems which sought the satisfaction of internal food demand; that is why such systems were mainly built in the country's inland, close to big urban centers.

Colombian irrigation developments gave very different results. For example, the establishment of the first irrigation systems in Tolima department, in the Madgalena valley, allowed the change from cattle-raising latifundia to capitalist enterprises of intensive exploitation and, consequently, caused the distribution of land to be less biased than in the rest of the department (Meertens, 2000). On the other hand, in Valle del Cauca department, the irrigation implemented by individuals was a facilitating factor in the expansion of the sugar cane mono-crop and the production means monopolization.

Although the Colombian Andean irrigation is thought to be directed mainly to family producers, we need to distinguish two sectors: the one in mountainous zones, where family farming prevails, and the one in the fertile and wide cundiboyacense high plateau, where, despite some presence of family farming, wide sectors of entrepreneurial producers oriented to dairy cattle and export flowers production stand out.

\section{c. Ecuador}

Cremers, Ooijevaar \& Boelens (2005, p. 4I) report that the Ecuadorian state invested vast sums of money in public irrigation infrastructure, which caused, in that time, I2 percent of the country's external debt. Despite that, the state-built systems only represent 220000 out of the 850000 irrigated hectares. These authors claim that the indigenous' and peasants' irrigation systems (mainly located in the Andes) were not benefited from those great investments.

In this country 86 per cent of the irrigated area is located on the coastal low zones, thanks to private, public and mixed systems, and the remaining I4 per cent is located in the High Andean zone (Maldonado Rojas, 2000), where most of the country's family farmers and 35.5 per cent of the agricultural surface are located (Forero Álvarez et al., 20II). Most of the formal irrigation systems in the Sierra have 
been originated by the state, although due to processes of transference from the state to communities, they are mixed nowadays. This distribution of irrigation could be added to the indicators of huge regional inequities in the development of Ecuadorian agriculture that Cochet \& Gasselin (2007) mention.

Although only a minority of small Ecuadorian family farmers has access to formal irrigation systems, they represent 88 per cent of the formal irrigators; they have between 6 and 20 percent of the rights to access water while the business agriculturalists (mainly located on the coast), who represent between I and 4 per cent of formal irrigators, have between 50 and 60 per cent of the rights to water access (Galarraga-Sánchez, 2000 in Cremers, Ooijevaar \& Boelens, 2005); the remaining percentage corresponds to non-identified medium irrigators. The difference between the number of irrigators and the assigned volume is explained by the size of exploitations, and also because 74 per cent of the irrigated area corresponds to private irrigation systems aimed, almost exclusively, at satisfying the needs of business agriculture on the coast.

\section{d. Perú}

Irrigated agriculture in Perú involves more than 600000 farmers (Solís, 200I). Although this country has long irrigation history, the current configuration started in the last third of the $19^{\text {th }}$ century thanks to coastal agriculture technological modernization processes which were stimulated by the perspectives on sugar cane and cotton exportations (Eguren, 2003). In this zone, the crops are favored by dry climate, good land quality, availability of water which comes from the Andes and allows the irrigation of coastal desert valleys, and the closeness to seaports and big centers for internal consumption.

The Peruvian agrarian reform between the years 1960 to 1970 allowed the family agriculture to currently dominate the agricultural panorama in the country, since 82.I per cent of the agricultural area corresponds to family farming (Forero Álvarez et al., 20II). Besides distributing land, this process also redistributed access to water for irrigation; 7I per cent of the irrigated lands were expropriated and given (Eguren, 2006) to family farmers or cooperatives made by them.

The Peruvian agrarian reform changed the agricultural land tenancy in the country radically. Nevertheless, it continued the historical model of a marked geographical division of irrigation and did not encourage an even distribution of irrigation systems. In the early 90's, when the agrarian reform had finished, only 26 per cent of the irrigation infrastructure was located in the Andes, where 56 per cent of the country's agricultural land is situated, while 68 per cent of the irrigated area 
was on the coast, where 28 per cent of the agricultural area is placed (Díaz Lima, 1995); the remaining agricultural and irrigated area was located in the plains of the Amazon basin, which have scarce population and agricultural activity.

From the 80's, the agrarian model changed and was oriented towards exportation; this favored the appearance of an "agrarian counter-reform" in which agro-exporting enterprises obtain big areas of land from family farmers, previous beneficiaries of the agrarian reform, or buy new lands, gained to the desert through irrigation, in public auctions (Eguren, 2003; 2006). This is the reason why, despite the agrarian reform, the private sector has about the third part of the irrigated surface (Maldonado Rojas, 2000).

The current processes which favor agro-exporting businesses have boosted the irrigation development on the coast and, therefore, have slowed down new developments in the Sierra. Nowadays there are 246000 hectares irrigated in the Sierra (Palerm-Viqueira, 2010, p. 785), which represents 20 per cent of the country's irrigated area; this means a decrease of 6 per cent with respect to what Díaz Lima (1995) reported.

\section{e. Venezuela}

Venezuela incremented its irrigation areas through programs for reinvesting petroleum profits, whose greatest boost took place in the 50's and was aimed principally at developing internal rather than export markets (Machado-Allison \& Rivas, 2004). In the 60's, the Venezuelan state rural development policies emphasized on the rural sector capitalization, more than on land or wealth redistribution. Colonization of new lands was encouraged, as well as irrigation systems construction, mechanization, electrification and supervised credit (Erasmus, 1967). The process of conditioning big areas for irrigation decayed towards the 90's (Angeliaume-Descamps \& Oballos, 2009).

Although most of the formally irrigated agriculture and the total of big scale irrigation systems are located in the low zones, the presence of Andean formal irrigation in hillsides is especially relevant. Venezuela is the only country in the region with a balanced geographical distribution of formal irrigation since the formal Andean irrigation systems correspond to 9 per cent of the 580000 hectares irrigated in the country, and the states where they are developed (Mérida, Táchira and Trujillo) constitute 8.9 per cent of the national agricultural surface. This is because vast conditionings were made in the Venezuelan Andean zone between the years 1970 and 1990 with the Valles Altos project where, thanks to temperature conditions lower than $15^{\circ} \mathrm{C}$ and irrigated agriculture, vegetables could be produced 
in order to satisfy the demand due to the changes in the urban diet. This project, which allows the irrigation of a total of 52458 hectares (Angeliaume-Descamps, Blot, Leroy, Maire \& Molina, 20II), is public and is almost exclusively directed to family farming. Despite being described as successful, Andean irrigation systems compete for water with urban centers, which deteriorates its quality.

In spite of the warning about data reliability and the lack of information about all the aspects in the Andean countries, a table is presented to summarize the existing data related to irrigation and agriculture.

TABLE l. Some data about irrigation and agriculture in Andean Countries

\begin{tabular}{|c|c|c|c|c|c|}
\hline & Bolivia & Colombia & EcuAdor & Perú & Venezuela \\
\hline $\begin{array}{l}\text { Family farming in the } \\
\text { whole country (\% of } \\
\text { agricultural area) (Forero } \\
\text { Álvarez et al., 20II) }\end{array}$ & 53 & 67 & 46 & 82 & 38 \\
\hline $\begin{array}{l}\text { Family farming in } \\
\text { the Andes (\% of } \\
\text { agricultural area) (Forero } \\
\text { Álvarez et al., 20II) }\end{array}$ & 99 & $7 \mathrm{I}$ & 72 & 82 & 58 \\
\hline $\begin{array}{l}\text { Private irrigation } \\
(\%)(\mathrm{FAO}, 20 \mathrm{I})\end{array}$ & $\begin{array}{c}8 \\
\text { (without } \\
\text { including } \\
\text { the mixed } \\
\text { systems) }\end{array}$ & 65 & 74 & 33 & $\begin{array}{l}\text { Scarce } \\
\text { information } \\
\text { about private } \\
\text { irrigation }\end{array}$ \\
\hline $\begin{array}{l}\text { Formal Irrigation } \\
\text { systems located in } \\
\text { the mountains (\%) }\end{array}$ & n.a. & $\begin{array}{c}4.4 \\
\text { (This work) }\end{array}$ & $\begin{array}{c}\text { I4 } \\
\text { (Maldonado } \\
\text { Rojas, 2000) }\end{array}$ & $\begin{array}{c}20 \\
(\text { Palerm- } \\
\text { Viqueira, 20I0) }\end{array}$ & $\begin{array}{c}9 \\
\text { (This work) }\end{array}$ \\
\hline $\begin{array}{l}\text { Total irrigated area } \\
(\mathrm{Ha})(\mathrm{FAO}, 20 \mathrm{I})\end{array}$ & 130000 & 906000 & 874000 & I 745000 & 580000 \\
\hline $\begin{array}{l}\text { Country's agricultural } \\
\text { area in the Andes (\%) }\end{array}$ & & & $\begin{array}{c}35.5 \\
\text { (Forero } \\
\text { Álvarez et } \\
\text { al., 20II) } \\
\end{array}$ & $\begin{array}{c}56 \\
\text { (Díaz Lima, } \\
\text { 1995) }\end{array}$ & $\begin{array}{c}8.9 \\
(\mathrm{FAO}, 2010)\end{array}$ \\
\hline Andean irrigators & n.a. & n.a. & $\begin{array}{l}88 \% \text { with } \\
\text { rights to water } \\
\text { access raging } \\
\text { between } 6 \text { and } \\
20 \% \text { (Cremers } \\
\text { et al., 2005) }\end{array}$ & n.a. & n.a. \\
\hline
\end{tabular}




\subsection{Informal irrigation and agricultural development}

Small and medium irrigation are widely extended in all the Andes altitudinal zones, which contributes to molding the agrarian landscape (Le Goulven \& Ruf, 1994). According to Zimmerer (2010, p. 337), such development is especially notorious in a diffuse strip located between 1000 and 3500 above sea level. In this altitudinal strip, which varies from one region to another, there is strong presence of indigenous and peasant irrigation systems (Bebbington, 1999; Ruf \& Mathieu, 200I; Trawick, 2003), which have been autonomously built by the family farmers themselves, without the state entities permit or support. In other words, most of them are informal irrigation systems.

Gutiérrez-Malaxechebarría (2013, p. 267) classifies informal irrigation into individual and collective systems. The individual ones correspond to those which have been executed by a producer under his own means, with his own production logics and without further considerations than his production system. Among the collective ones, he distinguishes between associative and communitarian; the communitarian irrigation systems work under a logic that takes water access as a right, while the associative systems consider the water resource as an asset as long as it makes part of the producer's investments.

Although most of the areas mentioned above have not been registered in statistics, they have actually been reported in the literature, either directly or indirectly. For example, in Ecuador it has been demonstrated that there are impacts produced by water overexploitation above the possibilities of superficial sources, which decreases the flow of the sources where the water is taken from (Girard, 2005; Ruf \& Gasselin, 1999; Vanacker et al., 2003). Information about water use regulations in systems managed by communities which do not follow the state logics is cited in Perú (Alfaro et al., 1993; Boelens \& Gelles, 2005; Brunschwing, 1986; Trawick, 200I), in Ecuador (Boelens \& Gelles, 2005), and for some cases in various Andean countries (Boelens \& Hoogendam, 2002; Coward, 1977; Maldonado Rojas, 2000; Vanacker et al., 2003).

The small size of informal irrigation systems, their eventual coexistence with formal systems, and the diversity of regulation forms, based on each community cultural patterns, result in them operating under a wide diversity of criteria. It is not rare to observe multiplicity of regulations in one same sector or basin as neither is it that conflicts arise; and land subdivision and new systems setup increase these phenomena.

Most of the traditional Andean irrigation infrastructure works are small ditches or channels whose intakes or inlets have been built with rustic materials (Alfaro et al., 1993, p. 137), and from the 80's an accelerated and wide use of hoses is observed. 
Farmers prefer to transport water by the action of gravity (Bernet, Hervé, Lehmann \& Walker, 2002, p. 376) and it is common that they use various sources simultaneously. They give preference to water from springs and slope streams rather than that from rivers that go along the valleys which, despite having enough flow all year long, would require the use of pumping equipment; that implies higher costs in taking water to the place where the crops are cultivated. This phenomenon is very well documented for the case of the Colca river valley in Perú, where the farmers take water from 103 sources (streams and springs) and distribute it for irrigation through 62 channels and 74 reservoirs (Robles Mendoza, 2010, p. 205); this is because taking water from the Colca river directly would imply pumping and, therefore, higher costs in infrastructure and maintenance.

Although documentary sources about informal irrigation are not many and are dispersed in a wide gamma of diverse type studies, some evidences of its existence in the five countries under study as well as its characteristics are shown below.

\section{a. Bolivia}

Ellis-Jones \& Mason (1999, p. 224) affirm that most of the Bolivian farmers use combinations of dry and irrigated agriculture; the irrigated agriculture precisely corresponds to informal systems which are not sustained in any type of agreement (Huibers, Moscoso, Durán \& Van Lier, 2004).

It can be inferred from Killeen et al. (2008) that, in the zones of recent colonization, irrigation is informal; such is the specific case of the eastern foothills. For instance, in the arid and semi-arid regions of the high plateau and valleys, most of the waste water is used in indirect and informal irrigation systems (Huibers et ál., 2004). On the other hand, Clark, Durón, Quispe \& Stocking (1999) confirm the existence of indigenous practices for soil conditioning in the high plateau which allow the establishment of furrow irrigation.

The international aid organisms support family farmers to provide themselves with irrigation systems and though they usually focus on communal systems, they have also sponsored individual irrigation solutions; such is the case of the installation of wells in Calicanto (Zimmerer, 20II), where the number of working systems is unknown since the systems installed directly by individual users must be added to the ones sponsored by cooperation agencies. By the way, Mcdowell \& Hess (2012) show the case of a community, apparently outside the main formal system, that could solve the conflicts caused by the climate change thanks to the support given by an international NGO to build a piping irrigation system. 
Despite the fact that in 2004 the Bolivian congress approved a law which recognized the rights to farming irrigation systems the irrigators' rights are actually poorly defined and subject to the requirements of sectors which compete for water access (Perreault, 2005); those requirements depend on a wide institutional plurality and norm ambiguity, which makes the irrigator's rights be either formal or informal (Zimmerer, 20II). This last author shows how the informal irrigation takes place along with the formal systems as in the case of the arrimantes, who are those irrigators outside the system's boundaries that use water from the systems and try to obtain formal rights, just as in the Laka Laka project.

\section{b. Colombia}

In Colombia great part of the irrigated areas expansion, especially in the Andean zone, has been the result of informal irrigation initiatives. In this sense, Sicard León \& Rodríguez Sánchez (2002, p. 16) say that in Colombia there are irrigation systems that "consist of rudimentary constructions which, by using hoses, conduct water to the properties from streams, wells or other superficial or underground water sources" and that, despite their importance, these systems do not appear in the statistics.

Gutiérrez-Malaxechebarría (2013) shows that in Colombia it is possible to find informal irrigation in the entire Andean region. In the analysis of the collected experiences, he demonstrated that most of the informal irrigation is individual, used by family producers, fed through piping which allows irrigation through sprinklers, and water is obtained through systems conceived for taking advantage of the altitudinal gradient. He also found that business agriculturalists that use informal irrigation are very few; they are located in plain zones, pump water from big rivers and, without exception, are individual irrigators.

\section{c. Ecuador}

In Ecuador, according to Le Goulven \& Ruf (1993), between 75 and 80 per cent of [some of] the Andean [agricultural] area is irrigated; however, according to official information, the agricultural irrigated area in this region is I4 per cent. The difference between the experts' perception and the official information (formally irrigated areas) means that most of the Andean irrigation is informal. In this sense, Herrmann (2002, p. 338) claims that 80 per cent of the irrigated area in some zones correspond to areas which are served with ancient channel irrigation systems built in the past centuries, just like the case he studies: farming irrigation systems in Tunghuragua, which has a potential to irrigate 56000 hectares. This system, built in 
the $\mathrm{I}^{\text {th }}$ century, was recuperated by farmers and indigenous in 1945 . It is an informal system since, despite being recognized by some state entities, it has not been legalized because of disagreements between the state and the irrigators in the 90's.

The Ecuadorian experts that were interviewed affirmed that, specially, but not exclusively, in the southern Andean region there are uncountable ditches and piping systems installed illegally by the irrigators themselves; these systems might compete with the supply to cities.

The above evidences, the scarce access to formal irrigation systems and the fact that Ecuadorian family agriculture (indigenous and farmers) represents 52 per cent of the agricultural production total value, using 46.I per cent of the harvested area (Forero Álvarez et al., 20II), allow us to suppose that these farmers use informal irrigation systems widely.

\section{d. Perú}

Communities in Perú demand the right to access water for irrigation; they argue that water and land have strong roots in the local norms and culture. Legalization of water access is given by its communal character rather than by the systems registration in the state formality. Some of these systems are formalized before the state as conflicts arise outside the community, like in the Coporaque case, in the Colca valley, studied by Vera Delgado \& Zwarteveen (2008), in which the community demanded the formal legitimacy of their rights to water when they faced the possibility that a large scale modern irrigation district which took water from their source was built.

The information reported about the Peruvian Andes emphasizes on ancestral and communal systems, but does not explain if they belong to formal or informal systems. These systems work through channels, which supply water permanently and spate irrigation, which carry water in different periods of time.

Informal irrigation systems can also be modern and of external origin, thanks to rural development projects promoted by NGO's. Bernet et al. (2002) show the case in which these programs encouraged sprinkler irrigation development in the Peruvian Sierra aiming at better efficiency than the one obtained before with channel irrigation. Nevertheless, this modernization and international recognition do not mean a step towards formality.

e. Venezuela

A recent proliferation of informal irrigation systems can be observed in the Venezuelan agriculture, where up to short time ago it was practically non-existent. 
Informal irrigation systems are especially observable in zones between I200 to 2000 meters above sea level. This process is explained by the farmers' migration from dry coffee crops to vegetables yields. On the other hand, Machado-Allison \& Rivas (2004) mention that there are non-registered small private irrigation systems in the state of Bolívar (low plain zone in the Guayana region). This means that Venezuela shows an increase of these systems, especially in family farming zones.

This can be happening because, according to Machado-Allison \& Rivas (2004), there has not been large scale infrastructure development lately, and because the state entities have left irrigation control unattended, which is why the responsibility for the actual systems and new projects development depend on private initiative.

\section{Conclusions}

This is the first work which revues irrigated agricultural development in the Andean countries as a whole. A geographical pattern is shown: large and medium formal systems in plain zones, especially in low lands, and small and informal irrigation systems in mountain zones, evidencing historical macroeconomic policies.

Irrigation systems are very varied, and so are the technologies and institutions that support them. Because of this, a differentiation between informal and formal systems is possible. However, review cases and analysis show that NGOs, users, and government support of irrigators groups have actually contributed to a blurring of the distinction between irrigation types in the Andean countries. In this sense, the differentiation between formal an informal irrigation is not clear and creates the room for maneuvering different interests, so lots of tensions are evident.

Water control is done under great diversity of institutions, which generates power struggles by agribusinesses or even extractive enterprises in all regions and in all categories, exacerbating tensions and conflicts. These processes could consolidate the state monopoly over water distribution; thus, a gradual pace towards formalization of informal systems is expected so that access to water can be assured.

In this way, and considering the fact that water distribution methods are sensitive to physical, political, social and institutional factors, which make it necessary to develop concordant mechanisms (Johansson, Tsur, Roe \& Doukkali, 2002) aimed at supplying the technical deficiencies, the states must incorporate community regulations and involve the users' experiential knowledge since many of these systems have offered local solutions for the efficient water use in modern systems 
(Coward, 1977). In other words, analyses and plans made to increase and formalize irrigated systems must incorporate cultural and environmental factors of every zone; similarly, the technical decision-making basis must be strengthened.

\section{Acknowledgements}

I want to thank Jaime Forero for his feedback on previous versions of this article. Also, thanks to Rudgerd Boelens, who read the draft and encouraged me to aim at its publishing; to Andres Eter, for helping me clarify the original idea which led to the article itself; and to Sonia Hernandez-Ocampo, who translated it to English.

\section{References}

Alfaro, J., Guardia, F., Golte, J., Masson, L. \& Oré, M. (1993). Riego y organización social. In Gestión del agua y crisis institucional: un análisis multidisciplinario del riego en Perú (pp. 129-15I). Lima: Tecnología Intermedia.

Andersson, K. \& Ostrom, E. (2007). An Analytical Agenda for the Study of Decentralized Resource Regimes. Working Paper 0I-07. Sanrem CRSP, Oired.

Angeliaume-Descamps, A. \& Oballos, J. (2009). Le maraîchage intensif irrigué dans les hautes vallées andines vénézuéliennes: quelle remise en question? Les Cabiers d'Outre-Mer, (247), 439-468.

Angeliaume-Descamps, A., Blot, F., Leroy, D., Maire, E. \& Molina, L. (20II). In A. Angéliaume-Descamps et al. (à paraître). Construction des ressources en eau au sein d'un espace agricole et protégé de montagne tropicale: les facteurs de la mise en place d’une gestion partici. Actes du colloque des Journées de Géographie Tropicales. Toulouse: L'harmattan.

Bebbington, A. (1999). Capitals and Capabilities: a Framework for Analyzing Peasant Viability, Rural Livelihoods and Poverty. World Development, 27(I2), 202I-2044. Bernet, T., Hervé, D., Lehmann, B. \& Walker, T. (2002). Small-Scale Sprinkler Irrigation for Milk Production Improving Land use by Slope Farmers in the Andes. Mountain Research and Development, 22(4), 375-382.

Boelens, R. (2009). The Politics of Disciplining Water Rights. Development and Change, $40(2)$, 307-33r. Last access on October $2^{\text {nd }} 2013$, from database Wiley Online Library, http://onlinelibrary.wiley.com/doi/ro.IIII/j.I467-7660.2009.01516.x/full 
Boelens, R. \& Dávila, G. (1998). Water Users’ Organizations, Support Approches, and the Defense of Equity. In R. Boelens \& G. Dávila (Eds.), Searching for Equity: Conceptions of Justice and Equity in Peasant Irrigation (pp. 419-460). Assen: Van Gorcum Ltd.

Boelens, R. \& Doornbos, B. (200I). The Battlefield of Water Rights: Rule Making Amidst Conflicting Normative Frameworks in the Ecuadorian Highlands. Last access on June, 20I4, from database Research Gate, http://www.researchgate.net/ publication/40I71270_The_Battlefield_of_Water_Rights_Rule_Making_Amidst_ Conflicting_Normative_Frameworks_in_the_Ecuadorian_Highlands

Boelens, R. \& Gelles, P. (2005). Cultural Politics, Communal Resistance and Identity in Andean Irrigation Development. Bulletin of Latin American Research, 24(3), 31I-327.

Boelens, R. \& Hoogendam, P. (2002). Water Rights and Empowerment. Assen: Van Gorcum Ltd.

Branch, N., Kemp, R., Silva, B., Meddens, F., Williams, A., Kendall, A. \& Pomacanchari, C. (2007). Testing the Sustainability and Sensitivity to Climatic Change of Terrace Agricultural Systems in the Peruvian Andes: a Pilot Study. Journal of Archaeological Science, 34(I), I-9.

Brooks, D. (2003). Pensar global pero actuar local: el caso del agua. Paper presented at Foro de las Américas. La concertación: instrumento para la gestión sostenible del agua dulce en el siglo XXI. La Paz.

Brunschwing, G. (1986). Sistemas de producción de ladera en altura. Bul. Inst. Fr. Et. And, XV(I-2), 27-52.

Canelón Pérez, J. (2008). Los bienes comunes: sentidos producidos sobre el agua en el Valle de Quíbor, Venezuela. Espacio Abierto Cuaderno Venezolano de Sociología, I7 (I), IO9-I42.

CIA (2009). World Fact Book. Last access on August 05 ${ }^{\text {th }}$, 20II, from http://www.cia. gov/cia/publications/factbook/geos/in.html

Cifdaloz, O., Regmi, A., Anderies, J. \& Rodríguez, A. (20ı). Robustness, Vulnerability and Adaptive Capacity in Small-Scale Social-Ecological Systems: the Pumpa Irrigation System in Nepal. Ecology and Society, I5(3), I-zo.

Clark, R., Durón, G., Quispe, G. \& Stocking, M. (1999). Boundary Bunds or Piles of Stones? Using Farmer's Practices in Bolivia to Aid Soil Conservation. Mountain Research and Development, I9(3), 235-240.

Cochet, H. \& Gasselin, P. (2007). A manera de conclusión: del interés de estudiar la mega diversidad agraria del Ecuador. In M. Vaillant et al. (Eds.), Mosaico agrario, 
Diversidades y antagonismos socio-económicos en el campo ecuatoriano (p. 318). Quito: Sipae, IRD, IFEA.

Coward, W. (1977). Irrigation Management Alternatives: Themes from Indigenous Irrigation Systems. Agricultural Administration, 4(3), $223-237$.

Cremers, L., Ooijevaar, M. \& Boelens, R. (2005). Institutional Reform in the Andean Irrigation Sector: Enabling Policies for Strengthening Local Rights and Water Management. Natural Resources Forum, 29(I), 37-50.

De Vos, H., Boelens, R. \& Bustamante, R. (2006). Formal Law and Local Water Control in the Andean Region: a Fiercely Contested Field. Water Resources Development, 22(I), 37-48.

Díaz Lima, C. (1995). Política liberal y proyectos de irrigación. Revista de la Facultad de Ciencias Económicas de la Universidad Mayor de San Marcos, (6), 98-107.

Dinar, A. \& Keck, A. (1997). Private Irrigation Investment in Colombia: Effects of Violence, Macroeconomic Policy and Environmental Conditions. Agricultural Economics, I6(I), I-15.

Eguren, F. (2003). La agricultura de la costa peruana. Debate Agrario, (35), I-37. Eguren, F. (2006). Reforma agraria y desarrollo rural en el Perú. In F. Eguren (Ed.), Reforma agraria y desarrollo rural en la región andina (p. 335). Lima: Cepes.

Ellis-Jones, J. \& Mason, T. (1999). Livelihood Strategies and Assets of Small Farmers in the Evaluation of Soil and Water Management Practices in the Temperate Inter-Andean Valleys of Bolivia. Mountain Research and Development, 19(3), 22I-234.

Erasmus, C. (1967). Upper Limits of Peasantry and Agrarian Reform: Bolivia, Venezuela and Mexico Compared. Ethnology, 6(4), 349-380.

FAO (2010). Sistema de informacion de la FAO sobre el agua y la agricultura.

Aquastat Data. Last access on June $8^{\text {th }}$, 2013, from http://www.fao.org/nr/water/ aquastat/main/indexesp.stm

Forero Álvarez, J., Corrales Roa, E., Estévez Moreno, L., Correa Pinilla, D., Galeano Medina, J., Villareal Fuentes, M., Gutiérrez-Malaxechebarría, A. (20II). Proyecto: Viabilidad económica y ambiental de sistemas de producción familiares agropecuarios sostenibles en los países andinos. Sispand I. Bogotá D.C: Pontificia Universidad Javeriana.

Girard, S. (2005). Les páramos, espace stratégique pour la gestion de l'eau dans les Andes septentrionales: le bassin-versant du río Ambato (Équateur). M@ppemonde, (78), I2.

Gutiérrez, Z. (2006). Riego campesino y diseño compartido. Gestión local e intervención en sistemas de riego en Bolivia. Lima: IEP. 
Gutiérrez-Malaxechebarría, A. (2013). Informal Irrigation in the Colombian Andes: Local Practices, National Agendas and Options for Innovation. Mountain Research and Development, 33(3), 260-268.

Gutiérrez-Malaxechebarría, A., Prime, S. \& Revillion, C. (2013). Irrigated Family Farming Panorama in the Latin-American Highlands. Cuadernos de Desarrollo Rural, Io(70), 93-II4.

Herrmann, P. (2002). Management Conflicts in the Ambato River Watershed, Tungurahua Province, Ecuador. Mountain Research and Development, 22 (4), 338-340. Huibers, F., Moscoso, O., Durán, A. \& Van Lier, J. (2004). The Use of Wastewater in Cochabamba, Bolivia: a Degrading Environment. In C. Scott, N. Faruqui \& L. Raschid (Eds.), Wastewater Use in Irrigated Agriculture: Confronting the Livelibood and Environmental (pp. 135-144). Ottawa: Commonwealth Agricultural Bureau International, Orient-Longman, and International Development Research Centre. ICID (2010). Annual Report 2009-2010. New Delhi: Autor. Last access on November 24 , 20II, from http://www.icid.org/ar_e_2009.pdf

Jáuregui, P., Olivares, R. \& Colque, L. (2005). Efectos del riego en los ingresos de las familias campesinas. Cochabamba: Programa de Desarrollo Agropecuario Sostenible, GTZ, Proagro Ucore.

Johansson, R., Tsur, Y., Roe, T. \& Doukkali, R. (2002). Pricing Irrigation Water: a Review of Theory and Practice. Water Policy, 4, I73-199.

Kay, C. \& Urioste, M. (2007). Bolivia's Unfinished Agrarian Reform: Rural Poverty and Development Policies. In A. Akram-Lodhi, S. Borras \& C. Kay (Eds.), Land, Poverty and Livelihoods in an Era of Globalization: Perspectives from Developing and Transition Countries (pp. 4I-79). New York: Routledge.

Killeen, T., Guerra, A., Calzada, M., Correa, L., Calderon, V., Soria, L., Quezada, B. \& Steininger, M. (2008). Total Historical Land-Use Change in Eastern Bolivia: Who, Where, When and How Much? Ecology and Society, I3(r). Last access on February $9^{\text {th }}$ 20I2, from http://www.ecologyandsociety.org/voliz/issi/art36/ Kuper, M. (20II). Option des destins croisés: regards sur 30 ans de recherches en grande hydraulique. Cabiers Agricultures, 20, 16-23.

Lam, W. (200I). Coping with Change: a Study of Local Irrigation Institutions in Taiwan. World Development, 29(9), 1569-1592.

Le Goulven, P. \& Ruf, T. (1993). The Functioning of Peasants’ Managed Irrigation in the Northern Ecuadorian Andes (Mira Watershed). In S. Manor \& J. Chambouleyron (Eds.), Performance and Measurement in Farmer-Managed Irrigation 
Systems. Proceedings of an International Workshop of the Farmer-Managed Irrigation System Network (p. 264). Colombo: International Irrigation Management Institute.

Le Goulven, P. \& Ruf, T. (1994). Funcionamiento del riego tradicional en los Andes ecuatorianos. Recomendaciones para el Plan Nacional de Riego. In Resúmenes de las comunicaciones presentadas en el ciclo de conferencias por los 20 años del Orstom en Ecuador (pp. 99-105). Quito: Orstom.

Machado-Allison, C. \& Rivas, J. (2004). La agricultura en Venezuela. Caracas: IESE.

Maldonado Rojas, T. (2000). Transferencia de sistemas de riego a los usuarios en países de América Latina y el Caribe (p. 44). Santiago: FAO. Last access on November 15 20II, from http://www.bosquesandinos.info/CESA/CESA_AG_or8ı.pdf

Mazabel, D. (2007). Apuntes sobre organización social y riego en México. Revista de Antropología Experimental, (7), 99-106.

Mcdowell, J. \& Hess, J. (2012). Accessing Adaptation: Multiple Stressors on Livelihoods in the Bolivian Highlands under a Changing Climate. Global Environmental Change, 22(2), 342-352.

Meertens, D. (2000). Ensayo sobre tierra, violencia y género $\left(2^{\text {nd }}\right.$ ed.). Bogotá D.C.: Universidad Nacional de Colombia/Centro de Estudios Sociales.

Morlon, P. (1996). Reducción de los riesgos climaticos por medio de acondicionamientos: el ejemplo de las heladas en el Altiplano. In Comprender la agricultura campesina en los Andes centrales: Perú-Bolivia (pp. 256-268). Lima: Travaux de l'IFEA.

North, D. (1993). Instituciones, cambio institucional y desempeño económico. México D. F.: Fondo de Cultura Económica.

North, D. \& Thomas, R. (1978). El nacimiento del mundo occidental, una nueva historia económica. México D. F.: Siglo XXI Editores.

Ortloff, C., Feldman, R. \& Moseley, M. (1985). Hydraulic Engineering and Historical Aspects of the Pre-Columbian Intravalley Canal Systems of the Moche Valley, Perú. Journal of Field Archaeology, I2(I), 77-98.

Ostrom, E. (1992). Crafting Institutions for Self-Governing Irrigation Systems. San Francisco: Center for Self-Governance.

Ostrom, E. (2000). El gobierno de los bienes comunes. La evolución de las instituciones de acción colectiva. México D. F.: Universidad Nacional Autónoma de México, Centro Regional de Investigaciones Multidisciplinarias, Fondo de Cultura Económica. Ostrom, E., Lam, W. \& Lee, M. (1994). The Performance of Self-Governing Irrigation Systems in Nepal. Human Systems Management, I3, 197-207. 
Palacios, P. (2003). Estudio sobre marcos normativos indígenas y consuetudinarios en la gestión del agua en el Ecuador. Quito: Walir, Eclac, Wageningen University.

Palerm-Viqueira, J. (2010). A Comparative History, from the $16^{\text {th }}$ to $20^{\text {th }}$ Centuries, of Irrigation Water Management in Spain, México, Chile, Mendoza (Argentina) and Perú. Water Policy, I2(6), 779-797. Last access on February Io ${ }^{\text {th }}$ 20I2, from http://cat.inist.fr/?aModele=afficheN\&cpsidt=23531793

Paz Ballivián, D. (1998). Fórmula trinitaria de la agricultura boliviana. Temas Sociales, (20), 7I-86.

Paz Ballivián, D. (2009). Estructura agraria boliviana. La Paz: Plural Editores.

Perreault, T. (2005). State Restructuring and the Scale Politics of Rural Water Governance in Bolivia. Environment and Planning, 37(2), 263-284.

Robles Mendoza, R. (2010). Sistemas de riego y ritualidad andina en el valle del Colca. Revista Española de Antropología Americana, 40(I), I97-2I7.

Roth, D., Rutgerd, B. \& Zwarteveen, M. (2005). Legal Complexity in the Analysis of Water Rights and Water Resources Management. In D. Roth, R. Boelens \& M. Zwarteveen (Eds.), Liquid Relations Contested Water Rights and Legal Complexity (pp. I-20). New Jersey: Rutgers University Press.

Ruf, T. \& Gasselin, P. (1999). Irrigation de montagne. Les Andes Equatoriens. Quito: ICID. Ruf, T. \& Mathieu, P. (200I). Water Rights and the Institutional Dynamics of Irrigated Systems: between State, Market and Community Action. International Journal of Water, I, 3-4.

Sicard León, T. \& Rodríguez Sánchez, L. (2002). Ciencia, tecnología, y ambiente en la agricultura colombiana. Bogotá D.C: ILSA .

Solís, J. (200I). Riego campesino: formas organizativas de regantes en comunidades andinas del Cusco. In Problema agrario en debate. Lima: IX Sepia.

Thenkabail, P., Biradar, C., Noojipady, P., Dheeravath, V., Li, Y., Velpuri, M. \& Dutta, R. (2009). Global Irrigated Area Map (GIAM), derived from Remote Sensing for the End of the Last Millennium. International Journal of Remote Sensing, 30(I4), 3679-3733.

Trawick, P. (200I). Successfully Governing the Commons: Principles of Social Organization in an Andean Irrigation System. Human Ecology, 29(I).

Trawick, P. (2003). Against the Privatization of Water: an Indigenous Model for Improving Existing Laws and Successfully Governing the Commons. World Development, 3I(6), 977-996. 
Urrutia Cobo, N. (2006). Sustainable Management after Irrigation System Transfer. Experiencies in Colombia-the RUT Irrigation District. Wageningen: Wageningen University.

Vanacker, V., Govers, G., Poesen, J., Deckers, J., Dercon, G. \& Loaiza, G. (2003). The Impact of Environmental Change on the Intensity and Spatial Pattern of Water Erosion in a Semi-Arid Mountainous Andean Environment. Catena, 51, 329-347.

Vera Delgado, J. \& Zwarteveen, M. (2008). Modernity, Exclusion and Resistance: Water and Indigenous Struggles in Perú. Development, 5I, II4-I2O.

Von Benda-Beckmann, F., von Benda-Beckmann, K. \& Spiertz, J. (1998). Equity and Legal Pluralism: Taking Customary Law into Account in Natural Resource Policies. In R. Boelens \& G. Dávila (Eds.), Searching for Equity. Conceptions of Justice and Equity in Peasant Irrigation (pp. 57-69). Assen: Van Gorcum Ltd.

Zimmerer, K. (1995). The Origins of Andean Irrigation. Nature, 378(6556), 48I-483.

Zimmerer, K. (2000). Rescaling Irrigation In Latin America: the Cultural Images and Political Ecology of Water Resources. Cultural Geographies, 7(2), 150-175.

Zimmerer, K. (2010). Woodlands and Agrobiodiversity in Irrigation Landscapes Amidst Global Change: Bolivia, 1990-2002. The Professional Geographer, 62(3), $335-356$.

Zimmerer, K. (20II). The Landscape Technology of Spate Irrigation Amid Development Changes: Assembling the Links to Resources, Livelihoods and Agrobiodiversity-Food in the Bolivian Andes. Global Environmental Change, $2 I(3)$, 917-934. 